Sc Marko Andrejić, kapetan I klase, dipl. inž.

\section{PRILOG DEFINISANJU I FORMALIZACIJI DNEVNOG PLANIRANJA I ORGANIZACIJE RADA U RADIONICAMA ZDRUŽENIH TAKTIČKIH JEDINICA}

$\mathrm{U}$ ovom radu je sagledano planiranje dnevnog rada $\mathrm{i}$ organizacije $\mathrm{u}$ radionici, sa aspekta organizatora - komandira jedinice za održavanje. Izvršena je formalizacija procesa planiranja, dat predlog izgleda plana i preporuke za uspešnu dnevnu organizaciju rada.

\section{Uvod}

Dnevno planiranje i organizacija rada veliki su problem vojne a i drugih organizacija. Još uvek nije formalizovana, standardizovana, niti razrađena jedinstvena metodika dnevnog planiranja $\mathbf{i}$ organizacije rada.

Sa primerima lošeg dnevnog planiranja $\mathbf{i}$ organizacije rada, susreće se svakodnevno u mnogim elementima organizacione strukture vojske (servisima, radionicama, komandama različitih nivoa, ustanovama), što ukazuje na to da se još uvek dovoljno ne shvata njegov značaj.

Baveći se (insistirajući na) višim ciljevima i strateškim problemima $i$ planovima ovaj elementarni, vremenski kratkotrajni segment u funkcionisanju vojne organizacije (čije se posledice nerešavanja provlače kroz sve segmente i faze u razvoju organizacije) zanemaruje se, što ima za posledicu niz negativnosti.

I pored ogromnog značaja za život i rad organizacije, dnevno planiranje i organizacija rada vrlo se oskudno tretiraju u dostupnoj literaturi, za razliku od planiranja koja se odnose na duži vremenski period ${ }^{1}$ ) (mesečno, tromesečno, polugodišnje i godišnje planiranje). Teoretičarima su ta saznanja teže dostupna, a praktičari (iskusni stručnjaci) čuvaju ih za sebe. Kod nas se za ta saznanja $i$ iskustva malo ko interesuje, jer se smatra da su to "sitnice" kojima se bave niži nivoi rukovođenja i komandovanja, zaboravljajući pri tome da se, nezavisno od statusne pozicije $u$ organizaciji, mora vršiti dnevno planiranje i organizacija rada. Priroda vojne organizacije je takva da je orijentisana na ljude čiji se rad mora planirati, kako bi se na osnovu tih planova kasnije vršilo usmeravanje napora $i$ aktivnosti prema ostvarenju određenih — zadatih ciljeva.

Dragocen izvor saznanja iz ove oblasti su stručnjaci koji su u praksi rešavali ove probleme, a i teorijski ih izučavali, tako da poznaju suštinu pro-

1) Godišnje i mesečno planiranje se, uglavnom, soliuno obrađuju $u$ dostupnoj literaturi $i$ časopisima, a odnose se pretežno na civilne proizvodne organizacije koje rade $u$ stacionarnim uslovima sa ustaljenom tehnologijom i organizacijom.

Opšte preporuke i načela mogu se preslikati i primeniti i na radionice (jedinice za održavanje), uz određene dopune koje važe za radionicu kao vojni kolektiv. 
blema, vladaju teorijom planiranja i metodikom rešavanja problema.

Među brojnim aktivnostima koje treba planirati u združenim taktičkim jedinicama (ZTJ), u okviru jedinstvenog dnevnog planiranja borbene obuke i vaspitanja, jeste i planiranje dnevnih zadataka i organizacije rada radionice.

Veliki problem pri planiranju dnevnog rada radionice ogleda se u neiznalaženju kompromisa u zadovoljenju interesa korisnika usluga radionice i interesa same radionice.

Dnevno planiranje i organizacija rada $u$ radionicama predstavljaju dijalektičko jedinstvo, i vrlo teško ih je posmatrati odvojeno jer su komplementarni, usmereni ka zajedničkom cilju, i međusobno se dopunjuju.

Cilj ovog rada (nadovezuje se na Planiranje mesečnog rada radionice $u$ ZTJ), jeste da:

- ukaže na potrebu i način dnevnog planiranja i organizovanja rada $u$ radionici, u uslovima smanjenja ljudskih resursa usled transformacije VJ, kako bi se povećala rentabilnost poslovanja, borbena gotovost jedinica za održavanje i smanjili utrošci i nenamensko korišćenje resursa radionice;

- olakša i unapredi rad planera dnevnog rada $\mathbf{i}$ organizacije $u$ radionicama u ZTJ i time poveća njihovu uspešnost $\mathbf{u}$ obavljanju funkcionalnih dužnosti;

- doprinese formalizaciji planiranja dnevnog rada i organizacije $u$ radionicama ZTJ;

- podstakne razmišljanje šireg kruga čitalaca na temu unapređenja mesečnog rada radionice.

\section{Potreba za dnevnim planiranjem i organizacijom rada}

Brojni uticaji okruženja (fizičkog i društvenog) i uslova života $i$ rada $u$ kojima radionica izvršava zadatke, zahtevaju potrebu za stalnim planira- njem dnevnog rada radionice $i$ iznalaženje organizacije koja će obezbediti uspešno izvršenje namenskih zadataka.

Svoje zadatke radionica izvršava $u$ uslovima velike "konkurencije» $\mathrm{i}$ istih kriterijuma za sve osnovne jedinice, bez dovoljnog uvažavanja specifičnosti njenog poslovanja.

Posledice lošeg dnevnog planiranja $\mathrm{i}$ organizacije rada u radionici manifestuju se u nemogućnosti realizacije mesečnog plana rada radionice, smanjenoj rentabilnosti poslovanja, smanjenoj borbenoj gotovosti jedinice za održavanje i ZTJ u celini, povećanim i nenamenskim trošenjem (upotrebom) resursa.

Mesečnim planiranjem ne može se dovoljno i potpuno obuhvatiti planiranje $i \mathrm{rad} u$ radionici, s obzirom na određena odstupanja, vanredne i nepredvidive obaveze (od strane planera mesečnog rada radionice), uslovljene promenama u širem okruženju zbog kojih vojska kao sistem i njeni pojedini elementi moraju reagovati na određeni način. Domet mesečnog planiranja rada radionice je ograničen $i$ racionalnim logičkim pristupom planiranju, koji ne dozvoljava preveliko detaljisanje u situacijama kada nedostaju određene kvalitetne informacije $\mathbf{i}$ za stanja sistema koja odlikuje određeni stepen neodređenosti, a i ulaganja (napore) koja bi bila veća od ostvarenih efekata. Ova praznina može se pokriti samo umešnim dnevnim planiranjem i organizacijom rada.

Dnevno planiranje rada radionice nije formalizovano i standardizovano, tako da je u praksi prisutna velika raznolikost, nejednak stepen uspešnosti rada radionica $\mathbf{i}$ otežano upravljanje radom radionica.

S obzirom na značaj dnevnog plana $i$ organizacije rada $u$ radionici, i na određene elekte koji se mogu njime postići (smanjenje utroška i nenamenskog trošenja resursa, povećanje rentabilnosti poslovanja, povećanje borbe- 
ne gotovosti jedinice za održavanje i ZTJ koju podržava radionica), nužno ga je razraditi, formalizovati i dati opšte preporuke za uspešnu dnevnu organizaciju rada.

Mesečni gubici resursa (vremenskih, novčanih i drugih), usled lošeg planiranja i organizacije rada, često su veći od prostog zbira dnevnih gubitaka.

Kvalitetnim dnevnim planiranjem i organizacijom rada stvara se povoljna organizacijska klima za izvršavanje zadataka.

Veliki broj ZTJ u strukturi VJ, i veliki značaj uspešnog funkcionisanja radionice za borbenu gotovost združenih taktičkih jedinica (kojeg nema bez dobrog dnevnog planiranja i organizacije rada) zahtevaju da se ovom problemu posveti više pažnje.

\section{Dnevno planiranje rada radionice}

Planiranjem mesečnog rada radionice [2] stvaraju se materijalne $\mathbf{i}$ druge pretpostavke za realizaciju rada radionice, kroz osmišljavanje i preduzimanje adekvatnih akcija u oblasti planiranja, organizovanja, komandovanja, koordinacije i kontrole. Te aktivnosti uzimaju se $u$ obzir i pri planiranju dnevnog rada $i$ organizacije $u$ radionici, ali u obimu koji je primeren vremenskom intervalu u kome će one "ispoljavati dejstvo«.

Prilikom planiranja dnevnog rada i organizacije $u$ radionici, ona se mora posmatrati integralno $u$ sastavu borbene obuke $i$ vaspitanja, $i$ pri tome $u$ zimati $u$ obzir uslove života $i$ rada $u$ ZTJ, veliku dinamiku aktivnosti, česte vanredne zadatke, određena sezonska kolebanja intenziteta rada i uspešnosti rada radionice (npr. zbog odsustvovanja rukovodećeg kadra), kao i ostala brojna organizaciona i tehnološka ograničenja.

Pri tome se radionica mora posmatrati kao radna organizacija koja mora zadovoljiti visok stepen rentabilnosti poslovanja, servis koji opslužuje korisnike njenih usluga (jedinice rodova i službi), i kao borbena jedinica koja mora obezbediti visoki stepen borbene gotovosti.

Veliki problem u dnevnom planiranju rada radionice jeste veliki broj subjekata čiji se rad planira (vojnici na odsluženju vojnog roka, vojnici po ugovoru, civilna lica, podoficiri) koji se razlikuju po ličnim osobinama, navikama, stepenu obrazovanja, vojnoevidencionim specijalnostima, stepenu stručnosti, itd.

Dnevno planiranje rada radionica obavlja se da bi se:

- planski zadaci u celosti ispunili $\mathrm{u}$ pogledu asortimana, termina i kvaliteta, odnosno ostvarila uspešna realizacija mesečnog plana rada radionice;

- radni proces $u$ radionici odvijao što više ritmički i kontinuirano; koristili;

— resursi namenski i optimalno

- svakoj organizacionoj celini na vreme prezentirali (dostavili) planski zadaci;

- udovoljilo potrebama i zahtevi„ma korišćenja obavezne radioničke, radne, nastavne, materijalne i druge dokumentacije;

- efikasno iskorištavala oprema i ljudski resursi;

- ostvario visok stepen iskorištenja prostora;

- ostvarilo efikasno i povoljno kretanje ljudi i materijala tokom radnog procesa;

- obezbedila komforna radna sredina i neophodni sanitarno-tehnički uslovi;

- obezbedio lak pristup opremi radi realizacije planskih zadataka, kako bi se izbeglo stvaranje uskih grla i povećanje dužine trajanja pojedinih aktivnosti, pojava zastoja i zakrčenja radnih mesta i prolaza, loš kvalitet rada i loši sigurnosni uslovi i povećani utrošak resursa. 
Pri planiranju dnevnog rada radionice potrebno je rešiti sledeće probleme:

- iznaći adekvatan način angažovanja jedinice za održavanje (radionice) i njenih delova kako bi se dnevno radno vreme maksimalno iskoristilo za realizaciju planskih funkcionalnih zadataka, koji proizilaze iz Mesečnog plana rada radionice i ostalih planova, zahteva korisnika usluga i naređenja pretpostavljenih organa;

- obezbediti maksimalnu dnevnu uposlenost stručne radne snage $\mathrm{i}$ ostalih elemenata organizacione strukture radionice;

- osmisliti adekvatne akcije koje treba svakodnevno preduzimati radi stvaranja povoljnih uslova za unapređenje organizacije rada $\mathbf{i}$ poslovanja $\mathbf{u}$ radionici, odnosno povećanja $\mathrm{b} / \mathrm{g}$ jedinice za održavanje i time ZTJ u celini.

Planiranje dnevnog rada radionice odvija se u tri faze:

- predviđanje,

- odlučivanje,

— izrada plana.

\section{Predviđanje}

U fazi predviđanja potrebno je:

- sagledati potrebe za angažovanjem radionice $\mathrm{i}$ identifikovati zadatke koji treba da se planiraju, na osnovu Mesečnog plana rada radionice i ostalih planova, zahteva korisnika usluga radionice, naređenja pretpostavljenih organa, poznavanja stepena realizacije zadataka od prethodnog dana i rezultata kreativne procene komandira jedinice za održavanje. Ove potrebe treba kvantifikovati i izraziti u norma-časovima;

- sagledati mogućnost za angažovanjem radionice, na osnovu poznate strukture-formacije radionice, dnevnog angažovanja ljudstva zavisno od strukture o kojoj se radi i (iz iskustva) poznatog koeficijenta organizacionih i tehnoloških gubitaka;

- odrediti adekvatnu strukturu, odnosno oblik grupisanja za izvršenje zadataka, koji proističu iz potreba za angažovanjem radionice (pojedinci, ekipe, tehnološke celine, kombinacija napred navedenih elemenata), uz uvažavanje organizacionih i tehnoloških gubitaka i formirati stablo strukture potrebne za izvršenje dnevnih zadataka (slika 1);

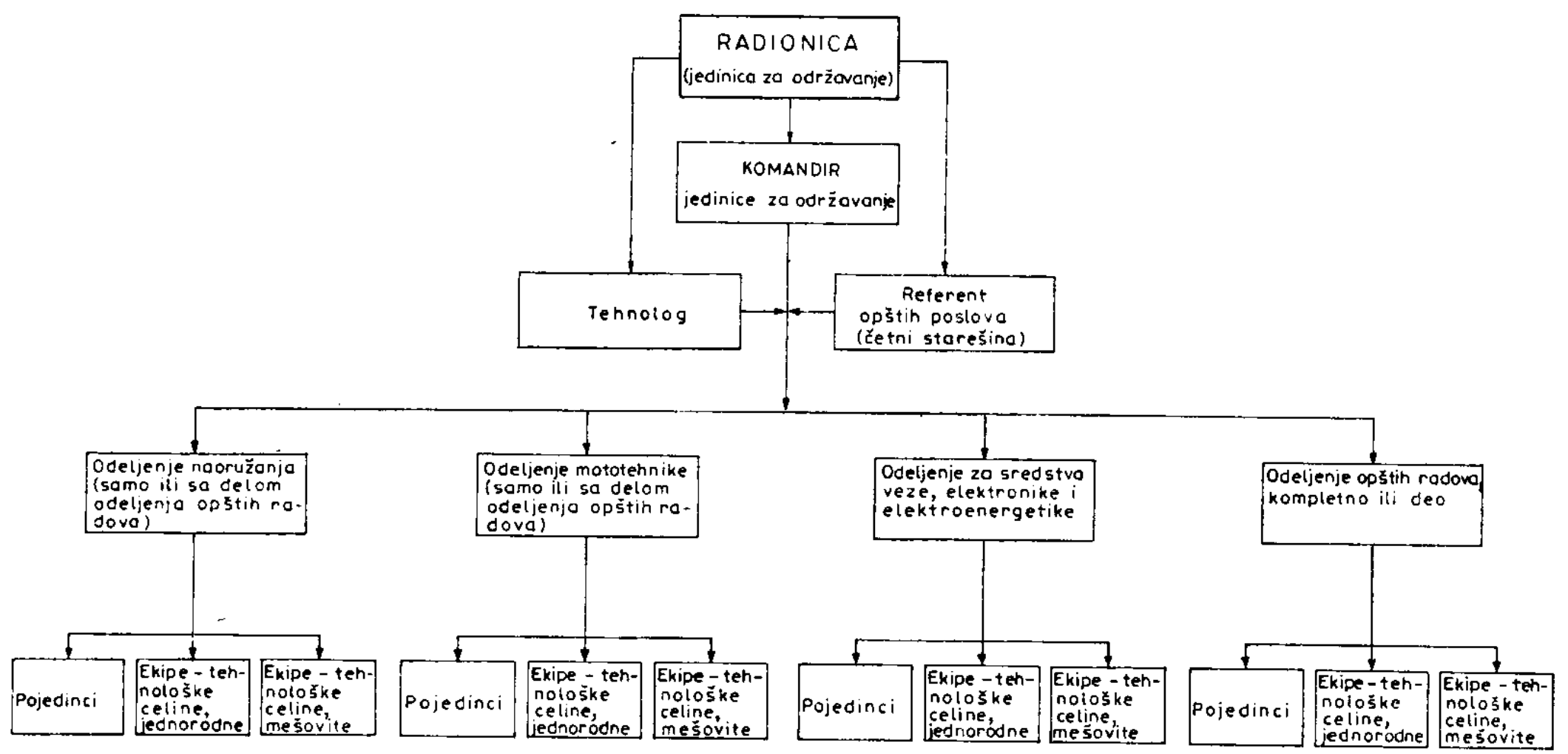

Sl. 1 - Stablo strukture koja izvršava dnevne zadatke radionice 
- odrediti odgovorne nosioce zadataka i izvršioce;

- pravilno formulisati zadatke odgovornim izvršiocima;

- iznaći povoljan način za dodelu zadataka potčinjenima i izvršiocima (upoznavanje sa zadatkom);

- sagledati pripreme koje je potrebno obaviti radi uspešnog izvršenja definisanih zadataka (moralne, psihološke, materijalne, stručne i organizacione); cijom;

- sagledati potrebe za koordina-

- sagledati potrebe za kontrolom (ključna mesta u procesu realizacije dnevnih zadataka);

- iznaći adekvatan način izveštavanja o stanju;

- sagledati posebno osetljiva mesta sa aspekta bezbednosti ljudstva, imovine i nesmetanog odvijanja radnog procesa;

- predvideti eventualne poremećaje u ustaljenom funkcionisanju radionice;

- sagledati vanplanske zadatke koji mogu biti dodeljeni radionici;

- sagledati način i potrebu pružanja određenih oblika pomoći komandirima organizacionih celina i neposrednim izvršiocima pojedinih zadata$\mathrm{ka}$;

- sagledati način upošljavanja civilnih lica, do dolaska vojnika sa jutarnje smotre;

- obezbediti pristup rezervnim delovima od samog početka radnog vremena, odnosno treba da budu dostupni kad god se za time ukaže potreba (pod uslovom da ih ima u magaci$\mathrm{nu})$; surse;

- sagledati potrebne novčane re-

- iznaći optimalan način rada (organizaciju) kojim se dnevni gubici (rashodi) svode na najmanju meru;

- iznaći adekvatan način koordinacije aktivnosti, kako bi se izbeglo skupljanje velikog broja TMS ispred radionice i ostali poremećaji koji stvaraju uska grla u ustaljenom funkcionisanju radionice kao organizacije;

- odrediti vremenske intervale u kojima se najbolje vidi "presek stanja», radi sprovođenja kontrole i pružanja pomoći;

- iznaći adekvatan način motivacije ljudstva za izvršenje zadataka;

- sagledati prioritete, od ranije poznate, naknadno određene prioritete i prioritete uslovljene tehnologijom radova (npr. zbog narušavanja hermetizacije sklopova i agregata, i dr.);

- identifikovati posebno opasna mesta pri radu, s obzirom na mogućnost povređivanja;

- sagledati neophodne mere bezbednosti i zaštite (zaštite na radu, higijensko-tehnološke zaštite, protivpožarne zaštite, i dr.) koje treba preduzeti s obzirom na prirodu zadataka koji se izvršavaju;

- sagledati moguća odstupanja od plana (naročito nedolazak TMS u radionicu) i koje aktivnosti realizovati da bi resursi radionice bili iskorišteni;

- sagledati dokumentaciju potrebnu za izradu određenih delova (manje složeni delovi za koje nije potrebna termička obrada);

- sagledati vojnostručnu literaturu potrebnu za izvršenje složenijih zadataka (tehnički pregledi i laki remont složenijih sredstava i sklopova);

- iznaći adekvatan sistem dnevne komunikacije;

- iznaći adekvatan način analize dnevnog rada radionice;

- obezbediti korektne međuljudske odnose $u$ radionici, pravilnu i pravičnu dodelu zadataka, materijalno i moralno stimulisanje za kvalitetno izvršenje zadataka;

- iznaći adekvatan način usmeravanja procesa rada i kontrolisanja ljudstva;

- iznaći optimalan način organizovanja radnih mesta kroz: sagledava- 
nje potreba za snabdevanjem radnog mesta materijalom, dokumentacijom i specijalnim alatom; obezbeđenje radnog mesta odgovarajućom radnom snagom i sredstvima za rad; obezbeđenje adekvatnog prostora, rasporeda sredstava za rad i materijala na radnom mestu, uprošćenje načina i smanjenje vremena rada na radnom mestu; smanjenje štetnog delovanja fizičko-hemijskih uticaja na radnom mestu i obezbeđenje zdravstvene opreme (optimalno radno mesto), itd.

\section{Odlučivanje}

Odlučivanje predstavlja opredeljenje za aktivnosti koje će ući u Plan, na osnovu sagledanih potreba za angažovanjem radionice koje proizilaze iz planova, zahteva korisnika usluga radionice, naređenja pretpostavljenih organa i kreativne procene komandira jedinice za održavanje.

Opredeljenje za aktivnosti koje će ući u plan vrši se poređenjem potreba za angažovanjem radionice sa mogućnostima radionice (izraženim $u$ norma časovima) uz uvažavanje određenih prioriteta.

\section{Izrada plana}

Ova faza je aktivnost tehničke prirode koja započinje još u fazi predviđanja.

Plan izrađuju komandir jedinice za održavanje i tehnolog (tamo gde ga ima) u radnoj beležnici, odnosno na formalizovanom obrascu (za sada nije zvanično propisan a $u$ radu se daje predlog njegovog izgleda) za celu je. dinicu, a komandiri organizacionih celina unose u radne beležnice zadatke (deo plana) koji se odnose na njihov sastav.

Da se komandiri organizacionih celina (radioničkih odeljenja) nebi opterećivali administrativno-planskim pos- lovima, neophodno je da dnevni plan rada radionice pokrije određene aktivnosti koje su zajedničke za više odeljenja.

U skladu sa Dnevnim planom rada radionice komandiri odeljenja mog $i$ vršiti dalju detaljizaciju određenih elemenata plana (naročito u delu koji se odnosi na dodelu zadatka), s obzirom da detaljno poznaju mogućnosti stručne radne snage, prirodu posla koji se obavlja, stepen realizacije započetih radova i ostale uticajne činioce.

Svaki izvršilac, na osnovu dobijenog zadatka osmišljava svoj lični plan na osnovu koga pristupa izvršenju zadatka. Ovi planovi znatno se razlikuju kod pojedinih izvršilaca, a uslovljeni su određenim specifičnostima koje pojedine izvršioce izdvajaju od ostalih.

Pri izradi dnevnog plana rada radionice neophodna je tesna saradnja komandira jedinice za održavanje sa organom TSl, komandantom pozadinskog bataljona i komandirima radioničkih odeljenja.

Dnevni plan rada radionice sadrži zadatke po elementima organizacione strukture $\mathrm{u}$ organizacionim celinama (zadaci od većeg značaja koje realizuju pojedinci, zadaci tehnoloških celina, grupa, ekipa, radioničkih odeljenja), dok planovi radioničkih odeljenja sadrže i precizne zadatke svakog pojedinca.

Plan koji radi komandir jedinice za održavanje i komandiri radioničkih odeljenja komplementarni su i usmereni ka zajedničkom cilju.

Dnevni plan rada radionice izrađuje se na osnovu:

- Mesečnog plana izvođenja borbene obuke i vaspitanja (aktivnosti planirane u Rasporedu borbene obuke i rada) jedinice za održavanje,

- Mesečnog plana rada radionice,

- Plana punjenja i kondicioniranja akumulatora, 
- Plana ispomoći jedinicama pri vršenju periodičnih pregleda,

- Plana veštačkog trzanja sistema artiljerijskih oruđa,

- Plana ispomoći jedinicama pri proveri veza,

- Plana ispomoći radionice jedinicama, pri realizaciji posebnih zadataka u ZTJ (komandantski pregledi, vežbe provere mobilizacijske $\mathrm{i}$ borbene spremnosti pojedinih jedinica, logorovanja, pojedinačna, odeljenska i vodna gađanja),

- naređenih prioriteta,

- naređenja primljenih od pretpostavljenih organa,

- zahteva jedinica i komandi,

- rezultata kreativnog predviđanja komandira jedinice za održavanje.

Dnevnim planom rada svakom izvršiocu (elementu organizacione strukture) treba precizirati:

- šta da uradi (tehnološki proces, proizvodni proces, posao, faze ra$\mathrm{da}$, operacije, zavisno od prirode i značaja zadatka, naziv TMS koja treba uzeti $\mathrm{u}$ rad $\mathrm{u}$ toku dana $\mathrm{u}$ pojedinim organizacionim celinama),

- koliko (kvantifikovati obim zadatka),

- $s$ kim (ko sarađuje, ko pruža stručnu a ko fizičku pomoć),

- $s$ čim (oprema i specijalni alat, potrebni $\mathrm{r} / \mathrm{d}, \mathrm{r} / \mathrm{m}$ i $\mathrm{p} / \mathrm{m}$ ),

- kako (način, postupak izvršenja pojedinih složenijih zadataka),

- gde (precizno mesto izvođenja),

- do kada (rok izvršenja zadat$\mathrm{ka)}$,

- način $i$ vreme izveštavanja o toku realizacije,

- pretpočinjavanje određenih elemenata organizacione strukture (radionice - jedinice za održavanje) drugim jedinicama,

- šta činiti ako se zadaci ne odvijaju prema predv:đenoj dinamici $i$ na očekivani način,
- prioritete.

Proces planiranja dnevnog rada radionice, pripreme za njegovu realizaciju $\mathrm{i}$ analizu realizacije, prikazani su na slici 2 .

Moguća (predložena) forma dnevnog plana rada radionice data je na slici 3 .

\section{Upoznavanje sa planom dnevnog rada radionice i dodela zadataka}

Praksa je pokazala da je poželjno ceo sastav radionice upoznati sa planom za naredni (tekući) dan, jer se time obezbeđuje neposredni kontakt 1 jedinstveno shvatanje plana (zadataka koji treba da se realizuju), izbegavaju nesuglasice, nejasnoće i proizvoljna tumačenja plana.

Pri upoznavanju sa Dnevnim planom rada radionice, komandir jedinice za održavanje, pored iznošenja zadataka koje pojedini elementi organi. zacione strukture treba da reše, ukazuje i na:

- delove koje treba prikupljati i gde, radi regeneracije $\mathrm{i}$ ponovnog korištenja;

- značaj pojedinih radova za b/g jedinice;

- nužnost kvalitetnog izvršavanja radova, samokontrole i uzajamne kontrole;

- posebno značajne faze rada, operacije ili posao u realizaciji zadataka;

taka;

- prioritete $u$ izvršavanju zada-

- posebno osetljiva mesta sa aspekata zaštite na radu i bezbednosti;

- potrebnu pripremu izvršioca (stručna, materijalna) radova;

- pretpočinjavanje pri izvršavanju zadataka:

- evidentiranje izvršenih radova u radioničkoj dokumentaciji (radioničke i radne liste); 

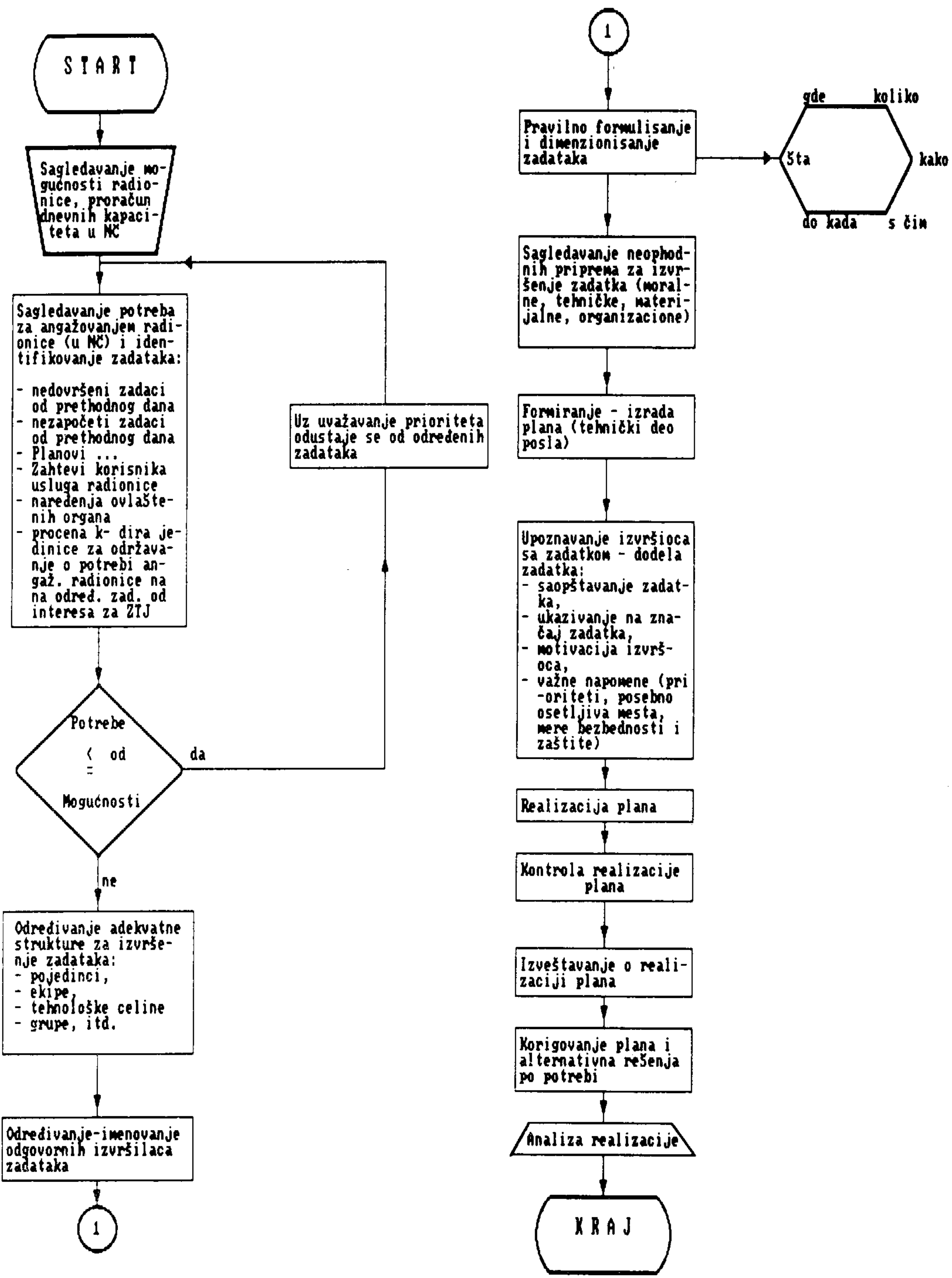

Sl. 2 - Proces izrade i sprovođenja Dnevnog plana rada radionice 


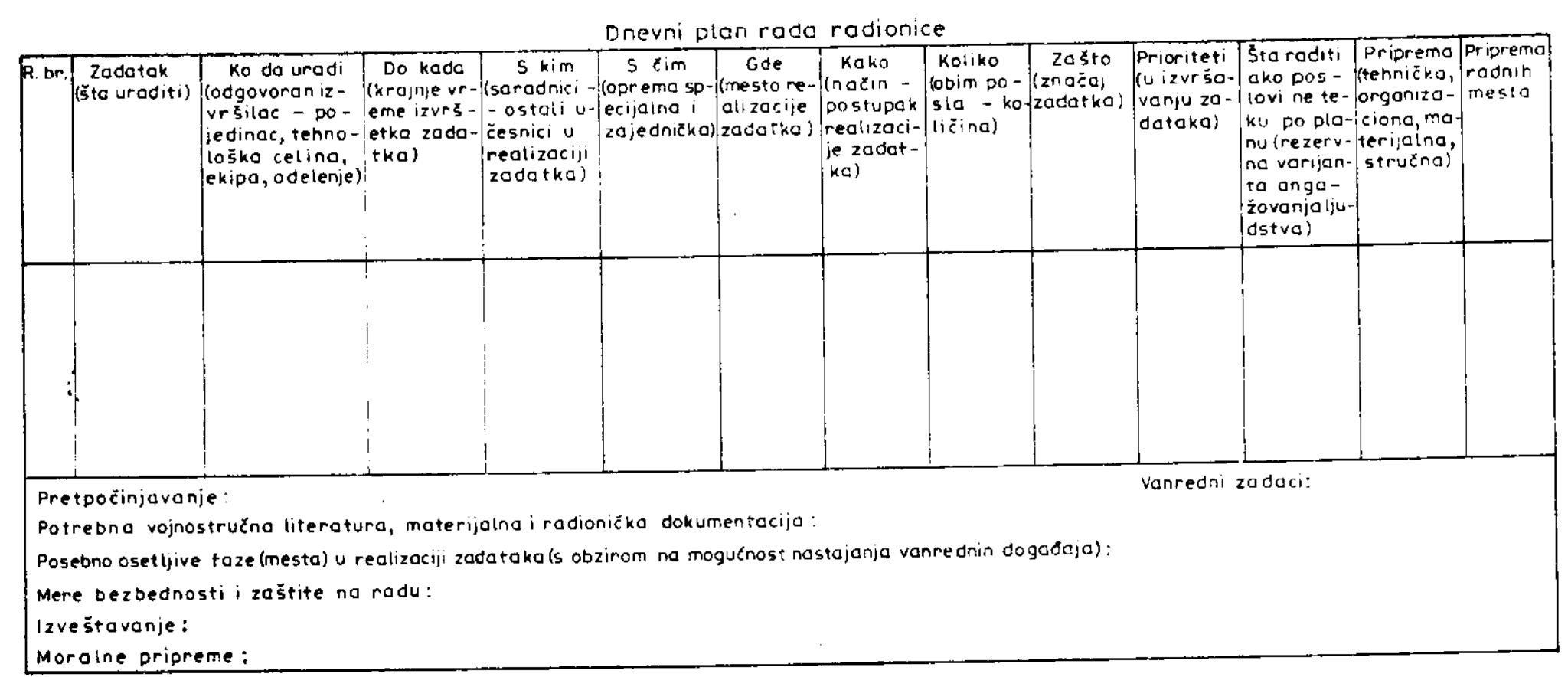

Sl. 3 - Dnevni plan rada radionice

- evidentiranje izvršenih radova u tehničkim knjižicama (tehnički pregledi, konzervacija, zamena pojedinih delova i sklopova, zamena radnih medija);

- evidentiranje utroška materijalnih resursa $\mathrm{u}$ materijalnim dokumentima (LIP-ovi r/d i dr.);

- evidentiranje podataka $u$ rasporedu borbene obuke i rada;

- postupak kod vanrednih oštećenja sredstava i povećanog utrošk. novčanih sredstava; lata;

- podelu specijalne opreme i a-

- dinamiku izvršenja određenih (posebno značajnih) zadataka, itd.

Prilikom dodele zadataka mora se voditi računa o delegiranju ovlaštenja od strane komandira radionice (da sve ne radi sam) već da izvesna ovlaštenja i slobodu u dodeli zadataka prepusti komandirima koji neposredno komuniciraju sa izvršiocima. Time se pozitivno utiče na ugled $i$ autoritet komandira jedinice za održavanje i komandira odeljenja.

Kod složenijih zadataka i zadataka koji duže traju, zbog velikog broja operacija koje treba realizovati i ote- žanog praćenja njihove realizacije, neophodno je da precizne zadatke izvršiocima izdaju komandiri odeljenja, na licu mesta, (npr. II tehnički pregled borbenih vozila).

$\mathrm{Na}$ kraju svakog radnog dana vrši se kritička analiza tekućeg radnog dana sa celokupnim ljudstvom radionice (mogu samo komandir jedinice za održavanje i neposredno potčinjeni komandiri, a da se ostalo ljudstvo upozna izvodno ili kombinacijom navedenih načina) i načelno upoznavanje sa sutrašnjim zadacima, a negde $i$ konkretizacija. Izjutra se vrši "ponavljanje « dodeljenih zadataka i dodela dopunskih (na osnovu dopunskih informacija, zahteva i zadataka).

Suvišno administriranje i »veliki proračuni« pri dnevnom planiranju rada radionice izbegavaju se kvalitetnm i brzim procenama zasnovanim na primeni logičko-formalne analize, insistiranjem na »stalnoj" angažovanosti ljudstva i primeni određenih logičkih procedura - pravila odlučivanja koja su podesna za vizuelnu komunikaciju i prilagođena perceptivnom sistemu čoveka. 


\section{Dnevna organizacija rada radionice}

Pod dnevnom organizacijom rada podrazumevamo način funkcionisanja radionice (kao organizacionog sistema) $\mathrm{u}$ toku radnog dana i hronološki redosled aktivnosti (prostorni i vremenski) koje se odvijaju u radionici.

U okviru dnevne organizacije rada radionice, komandir jedinice za održavanje mora sebi, u toku radnog dana (u svom ličnom planu), obezbediti vreme za:

- rad,

- usavršavanje,

- razmišljanje,

— opuštanje - odmor (aktivan ili pasivan).

Za navedene aktivnosti $u$ okviru dnevnog radnog vremena treba obezbediti vreme i za ostalo ljudstvo zavisno od njihove statusne pozicije u organizaciji (radionici) i prirode zadataka koje izvršavaju.

Neophodno je da se predviđanjem ide ispred pojava koje mogu usloviti zastoje u radu i odstupanja od osnovnih zadataka koje radionica realizuje.

Komandir jedinice za održavanje osnovni je planer i organizator borbene obuke i vaspitanja, i glavni pokretač akcija u svojoj jedinici. Svojim akcijama i naporima stvara povoljnu organizacijsku klimu, uobličava kolektivni život i stvara uslove (obezbeđuje) da jedinica - radionica, funkcioniše kao skladna celina. Samo tamo gde postoji kvalitetno planiranje i organizacija rada, postoji i dobra motivisanost članova organizacije, jer iz toga se vide stremljenja ka nečemu (ciljevi) i svrha svega što se radi.

Pri dnevnom planiranju i organizaciji rada radionice posebno dolazi do izražaja organizatorska sposobnost, kreativnost, pronicljivost, sugestibilnost, smisao za saradnju i rad sa ljudima, te i druge sposobnosti koman- dira jedinice za održavanje i komandira organizacijskih celina u njenom okviru (odeljenja, vodova). Ovaj problem otvara, pored ostalih, i pitanje »kako organizovati rad i kako sam raditi da bi bio uspešan $i$ cenjen u radionici jedinici za održavanje i ZTJ .

Ključna ličnost u planiranju i organizaciji dnevnog rada $u$ radionici je komandir jedinice za održavanje, pa zbog toga njegovom radu i ponašanju treba posvetiti najviše pažnje.

Komandiri radioničkih celina (odeljenja) osnovni su izvođači borbene obuke i vaspitanja, odnosno realizatori aktivnosti koje planira komandir jedinice za održavanje. Njihov doprinos planskoj funkciji ogleda se u davanju korisnih informacija $\mathrm{i}$ predloga $\mathbf{i}$ daljoj operacionalizaciji plana koji izrađuje komandir jedinice za održavanje (naročito u delu koji se odnosi na dodelu zadatka svakom izvršiocu).

$S$ obzirom na to da je komandir jedinice ključni subjekat u uspostavlja. nju efikasne dnevne organizacije rada u radionici, neophodno je sagledati aktivnosti koje $u$ toku radnog vremena treba da realizuje komandir jedinice za održavanje.

Redosled aktivnosti, uz neznatna odstupanja, uslovljena specifičnošću uslova u kojima pojedine jedinice za održavanje izvršavaju zadatke, treba da bude:

- dolazak u kasarnu (jedinicu);

- informisanje kod dežurnog oficira ZTJ o stanju u jedinici;

- informisanje $e^{2}$ ) kod dežurnog pozb o stanju u jedinici;

- prijem raporta od dežurnog jedinice za održavanje;

2) Do početka rada $u$ radionici aktivnosti treba maksimalno iskoristiti za zatvaranje informacionog ciklusa neophodnog za rešavanje većine problema koji bi mogli opterećivati organizaciju - radionicu u toku dana, ili se na bilo koji način reflektovati na njeno' stanje. Takođe, to vreme treba iskoristiti i za stvaranje pozitivne organizacijske klime i pozitivne motivacije izvršilaca poslova, posebno promenljivog sastava (vojnici na odsluženju vojnog roka). 
- obilazak kruga koji održava jedinica za održavanje i prostorija za smeštaj ljudstva;

- obilazak radioničkih prostora i utvrđivanje prisutnosti na poslu;

- obilazak ostalih organa unutrašnje službe (ako ih ima);

- razgovor sa komandantom pozadinskog bataljona i načelnikom TSl;

- razgovor sa korisnicima usluga radionice tekućeg dana;

- prisutnost na jutarnjoj smotri;

- postrojavanje cele jedinice is. pred radionice i upoznavanje sa dnevnim planom rada (ponavljanje zadataka izdatih na kraju prethodnog dana pred postrojenom jedinicom); ${ }^{3}$

- obilazak radioničkih odeljenja - pogona, radi pružanja pomoći oko uspešnog početka radnog dana;

- obilazak magacina $\mathrm{r} / \mathrm{d}$ i servisne stanice;

- obilazak ljudstva na radnim mestima 2 do 3 puta dnevno, pružanje pomoći i kontrola (u trenutku kada se intelektualno zamori od rutinskih ili kreativnih poslova) $)^{4}$;

- realizacija određenih aktivnosti i zadataka planiranih u Rasporedu bor. bene obuke i rada; be;

- smena organa unutrašnje služ-

- obavljanje službenih razgovora sa potčinjenima;

- globalna analiza dnevnog rada sa celokupnim sastavom radionice, $\mathrm{u}$ kazivanje na propuste $\mathrm{i}$ izdavanje $\mathrm{za}$ dataka za naredni dan; ${ }^{5}$ )

3) Posle toga komandiri organizacionih celina odvode svoje ljudstvo na radna mesta $i$ izdaju konkretne zadatke.

4) Prilikom sprovođenja ove aktivnosti treba postupati mudro i oprezno, uz uvažavanje različitosti strukture koja se obilazi - kontroliše (vojnici na odsluženju vojnog roka, civilna lica, podoficiri, oficiri).

5) Dnevni rad komandiri odeljenja analiziraju »u hodu« na radnim mestima, ili zajedno sa svojim ljudstvom, pre analize koju vrši komandir jedinice za održavanje.
- detaljna analiza radnog dana $^{6}$ ) sa komandirima organizacionih celina i radni dogovor za naredni dan;

- lična priprema i stvaranje uslova za realizaciju plana za naredni dan.

Svakodnevno provođenje ovih aktivnosti posebno je značajno zbog promenljivog sastava (u proseku ga čini oko $70 \%$ od ukupnog brojnog stanja jedinice za održavanje), jer se time postepeno utiče na formiranje određenih pozitivnih radnih navika i opšteprihvatljivih vrednosti kod potčinjenih, naročito kod mladih, izgrađuje i razvija određeni sistem rada $u$ jedinici za održavanje i svakodnevno stiče uvid u stanje.

Radi uspešnog dnevnog planiranja i organizacije rada radionice, od komandira jedinice za održavanje zahteva se tesna saradnja sa upravnim organom tehničke službe (TSl) i drugim organima komande, komandirima osnovnih jedinica, komandama i neposredno potčinjenim organima.

\section{Preporuke za uspešno funkcionisanje radionice}

Polazeći od prirode vojne organizacije, uslova života i rada u ZTJ i zadataka koje radionica izvršava, mogu se sistematizirati određene preporuke za rad na stvaranju uslova i obezbeđenju uspešnog dnevnog funkcionisanja radionice kao organizacije i vojnog kolektiva.

Ove preporuke usmerene su na rešavanje (sprečavanje nastajanja) problema organizacione, stručne i ljudske prirode. S obzirom na to da su problemi organizacione i stručne prirode ta-

6) Dosadašnja praksa je pokazala da se dnevna i mesečna analiza rada radionica vrši površno, pri mesečnim analizama rada radionice gubici resursa (uglavnom kapaciteti radne snage izraženi u norma-časovima) izražavaju se ukupno, tako da se uopšte (ili vrlo retko) razmatraju pravi uzroci neostvarenja plana, odnosno dnevni gubici resursa i dnevna odstupanja od plana. 
kođe ljudski, vrlo ih je teško razdvojiti. Zbog toga ce se taksativno nabrojati određene preporuke kojih se treba pridržavati radi uspešnog funkcionisanja radionice, bez njihovog izdvajanja i svrstavanja u navedene grupe:

- rad komandira jedinice za održavanje, tehnologa i referenta opštih poslova mora biti u f :nkciji stvaranja uslova za realizaciju proizvodnih zadataka;

- kontinuirano razvijanje pozitivnih vrednosti i navika;

- stvorenu organizaciju rada $\mathrm{i}$ uhodanu hronologiju odvijanja aktivnosti koje se ciklično ponavljaju usavršavati postepeno i bez naglih promena;

- kvalitetno uobličavati kolektivni život i sprečavati nastajanje konfliktnih situacija;

- stalno insistirati na kvalitetu i kvantitetu rada;

- stalno insistirati na korišćenju formacijske opreme i poštovanju propisanih tehnologija;

- za radne sastanke pripremati se temeljito i dobro ih organizovati, a diskusije na sastancima usmeravati ka definisanom cilju;

- radi sticanja uvida u stanje, kontrole i pomoći, i pružanja pozitivnog doprinosa unapređenju ukupne organizacije života i rada, povremeno provoditi 24 časa u jedinici;

- kontinuirano izučavati sistem rada $\mathrm{i}$ odnose u bližem i daljem okruženju u kome radionica posluje - izvršava zadatke, i postepeno im se prilagođavati;

- redovno informisanje i praće nje informacija koje ulaze u sistem neformalnim komunikacijama (neformalne komunikacije ne treba gušiti, jer mogu proizvesti suprotne efekte, već ih smanjivati jačanjem formalnog komuniciranja);

-- obezbediti da neposredno potčinjeni organi poseduju više dominan- tnih znanja (informacija) od njima potčinjenih (izvršilaca);

- razvijati i podsticati inicijativu i stvaralački duh;

— podsticati ljude da slobodno iz. nose svoje predloge koji se odnose na poboljšanje organizacije rada, a takođe i svoje probleme;

- insistirati na odgovornosti;

- upravljanje, rukovođenje i komandovanje $u$ radionici posmatrati kao interpersonalan, recipročan psihodinamičan odnos; dioce;

- razvijati poverenje $u$ rukovo-

- uvažavati neposredno potčinjene rukovodioce;

- obećanja ispunjavati;

- svakodnevno raditi na podizanju standarda i komfora potčinjenih, kao i ostalih činilaca humanizacije rada;

- neprekidno stvarati uslove za samopotvrđivanje i jačanje samopouzdanja i ljudi;

- povremeno sebe $\mathrm{i}$ neposredno potčinjene izlagati dokazivanju i potvrđivanju sposobnosti, radi jačanja neformalnog i potvrđivanja formalnog autoriteta, u aktivnostima koje realizuju neposredno potčinjeni (sklapanje i rasklapanje sredstava, pravilnoj upotrebi TMS, dijagnostici neispravnosti, frontalnim nastupima u kriznim situacijama);

- orijentisanost na ljude i (proizvodni) rad;

- svakodnevno insistirati na visokom stepenu odgovornosti i biti odgovoran;

- neformalnim kontaktima u bližem i daljem okruženju stvarati uslove za uspešnost rada radionice (obezbeđenje rezervnih delova, informacije, dokumentacija, itd.);

- stimulativne mere primenjivati kad god za to postoji zakonska ili logička osnova;

- pokazati smelost da se prihvati rizik i biti odlučan; 
- neprekidno raditi na dnevnom rešavanju problema neposrednih izvršilaca i na njihovoj pozitivnoj motivaciji za izvršenje zadataka;

- voditi računa o usavršavanju 1 napredovanju potčinjenih;

- interesovati se za rad i ponašanje ljudstva koje izvršava zadatke izvan matične jedinice;

- svakodnevno isticati dobre i loše strane $\mathrm{u}$ radu;

- stvaranjem pozitivne organizacijske klime stvarati preduslove da kolektiv javno osuđuje ono što je negativno, a da prihvata i podstiče sve pozitivne predloge $\mathrm{i}$ inovacije;

- mesec dana po dolasku većeg broja ljudi u jedinicu za održavanje radionicu (u prekomandu), izvršiti anketiranje promenljivog sastava (vojnika) radi utvrđivanja stepena kohezije i "prirodnog vođe», a zatim ga pridobiti i za formalnog vođu (unapređenje, postavljanje na višu statusnu poziciju - komandir grupe, predradnik, vršilac dužnosti, i sl.);

- svakodnevno stvarati uslove za međusobnu (uzajamnu) kontrolu kvaliteta i kvantiteta rada;

- pri izdavanju zadataka insistirati na povratnoj reakciji primaoca poruke (zadatka);

- svakodnevno osposobljavati neposredno potčinjene da pravilno shvate zadatak uz iznošenje što manje činjenica;

- svakodnevno kontaktirati sa pretpostavljenima i potčinjenima;

- svakodnevno pratiti zakonitosti odvijanja života $\mathrm{i}$ rada $\mathrm{u}$ radionici, kako bi se pravovremeno naslutïla veća sezonska (periodična) kolebanja u ustaljenom načinu rada;

- krajnji cilj rada treba da bude zadovoljenje interesa korisnika usluga radionice;

- voditi računa o prioritetima pri dodeli zadataka;
- pri rešavanju problema orijentisati se na ključne, tj. na one koji najviše "opterećuju organizaciju (najuticajniji na $b / g$ jedinice angažuju najviše ljudskih, odnosno materijalnih resursa);

- svakodnevno pratiti radna mesta i raditi na opisu zadataka za svako radno mesto;

- kontrolu i obilazak neposrednih izvršilaca radova vršiti, uglavnom, sa neposredno potčinjenim rukovodiocima u vreme "radne pauze" na svom radnom mestu;

- uz uvažavanje specifičnosti svakog radnog mesta ići na unifikaciju pri dodeli zadataka, jer to skraćuje vreme;

- stvoriti uslove za brzo reagovanje (po unapred razrađenom postupku i logici zaključivanja) na poremećaje i sistemu i ustaljenoj organizaciji rada;

- planirati uvek, danas za sutra, to zapisati, a sutradan se podsetiti zapisanog;

- redovno informisati ljudstvo o problemima u radu i ostvarenim rezultatima;

- biti istrajan da se izdati zadaci potpuno realizuju;

- obezbediti da svaki pojedinac dobija zadatak samo od jednog čove$\mathrm{ka}$;

- ne tražiti idealnu organizaciju, već je stvarati od raspoloživih resursa;

- raditi na dijalektičkoj sintezi procesa rada $i$ procesa upravljanja, radi stvaranja početnih uslova za čvrstu integraciju kolektiva;

- u slučaju pomeranja rokova, ne menjati uspostavljenu organizaciju rada već samo povećati intenzitet rada;

- u kriznim situacijama nekada treba reagovati verbalno; nekada odraditi deo posla bez verbalnih intervencija, a nekada se treba »jednostavno skloniti« i sačekati da se situacija smiri prirodnim tokom, itd. 


\section{Zaključak}

Uspešno dnevno planiranje i organizacija rada podrazumevaju planiranje kapaciteta (potreba i mogućnosti), planiranje prioriteta, planiranje troškova, usklađivanje rokova i obezbeđenje uspešnog funkcionisanja radionice kroz oživljavanje organizacione strukture $\mathrm{i}$ integrisanje čoveka $u$ svrsishodno zajedničko delovanje.

Sve izraženije smanjivanje resursa svih vrsta i neadekvatna popuna kadrom zahtevaju veću centralizaciju planiranja i dosledno poštovanje prioriteta.

Planiranje dnevnog rada i organizacije rada radionica u združenim taktičkim jedinicama, jeste aktivnost ko. ja direktno utiče na povećanje rentabilnosti poslovanja radionice $i$ borbene gotovosti ZTJ. Zbog toga treba stalno insistirati na planiranju $i$ obezbediti da se u teorijskim razmatranjima što bolje rasvetli, a zatim implementira u praksi.

S obzirom na veliku različitost a planiranju dnevnog rada radionice, potrebno ga je u što većoj meri standardizovati i formalizovati, radi jedinstvenog pristupa u svim ZTJ VJ. Time će se upravljanje radom radionice učiniti efikasnijim i znatno smanjiti utrošci resursa.

Stručnom deskripcijom procesa planiranja i organizacije dnevnog rada radionice stvara se polazna osnova za formalizaciju, a zatim i automatizaciju planiranja borbene obuke i vaspitanja u jedinici za održavanje.

Prezentirana formalizacija planiranja dnevnog rada $i$ organizacije u radionici predstavlja jedno od mogućih rešenja na putu iznalaženja optimal. nog. Njime se ne ograničava sloboda i kreativnost planera da u skladu sa vlastitom rukovodilačkom intuicijom, iskustvom, kreativnom procenom (predviđanjem) i konkretnim uslovima rešava probleme iz domena planiranja dnevnog rada $\mathrm{i}$ organizacije $\mathrm{u}$ radionici, već nudi jedno rešenje zasnovano na iskustvu, intuiciji i sistemskom pristupu u rešavanju problema $u$ organizacionim sistemima.

Ponuđene preporuke za kontinuirani rad na uspostavljanju uspešne dnevne organizacije rada i za uspešno funkcionisanje radionice su opšte i mogu se primeniti na većinu radionica u ZTJ VJ, ali su »nepotpune«. Neophodna je njihova nadopuna (zasnovana na proračunima $i$ istraživanju konkretnih aktera), uslovljena specifičnostima svake organizacije (radionice).

\section{Literatura:}

[1] Andrejić M.: Planiranje mesečnog rada radionice za tehničko održavanje u združenim taktičkim jedinicama, seminarski rad, VVTS, Zagreb, 1991.

[2] Andrejić M.: Prilog planiranju mesečnog rada radionice za tehničko održavanje u združenim taktičkim jedinicama, VTG br. 1/95.

[3] Andrejić M.: Prilog planiranju mesečnog rada radionice za tehničko održavanje u združenim taktičkim jedinicama - nastavak, VTG br. 2/95.

[4] Mileusnić iN.: Savremena organizacija rada, Rad, Beograd, 1969. 